\title{
Lessons learnt from the snow emergency management of winter season 2008-2009 in Piemonte
}

\author{
R. Pelosini, S. Bovo, and M. Cordola \\ Arpa Piemonte, Via Pio VII 9, 10135 Torino, Italy \\ Received: 8 March 2010 - Revised: 7 May 2010 - Accepted: 28 June 2010 - Published: 16 February 2011
}

\begin{abstract}
The winter season 2008-2009 has been characterized by heavy snowfalls over the western Alps. The snowfalls have been exceptional because of their earliness, persistence, intensity and territorial spread. The impact on the regional environment and territory has been relevant, also from the economical point of view, as well as the effort of the people involved in the forecasting, prevention and fighting actions. The environmental induced effects have been shown until late spring. Several snowfall events affected also the plains and the main towns, causing social impacts. The purpose of this work is to describe the overall effects of the anomalous snowfalls and the emergency response by the local government and institutions to face the hazard scenario and mitigate the risk for people, properties and environment. Arpa Piemonte (Regional Agency for Environmental Protection) gave the technical support to the snow emergency management borrowing the expertise acquired during the heavy hydrological events occurred in the Piemonte region and contributing to minimize losses. A short list of recommendations came out from the experience, as well as the technical tools and products, all highlighting the emergency preparedness relevance.
\end{abstract}

\section{The winter 2008-2009 heavy snowfalls}

The main critical situations have been arisen from the snowfalls earliness in season, the several snow precipitation events over the plains, the big amount of snow accumulation on the ground, as well as the anomaly with respect to the last $30 \mathrm{yr}$ climatic trend of snow conditions in the western Alps. The high-density snow depth manual station network (see Fig. 1) allows performing a reliable climatological analysis.

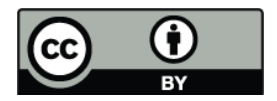

Correspondence to: R. Pelosini (r.pelosini@arpa.piemonte.it)
As shown in the Fig. 2, the gap of the mean daily new snow accumulation with respect to the climatology started from November, increased in December significatively and persisted throughout the spring season.

As the snow in the mountain is concerned, see Fig. 3, the 2008-2009 winter has been characterized by a large amount of new snow with respect to the climate, with snow amount up to the $99 \%$ above the average. In three alpine sectors it has been the snowiest season since 1966 .

Several snowfall events affected also the plains and main towns. 14 significant snow events have been recorded in $\mathrm{Cu}$ neo and 9 in Torino from December 2008 to March 2009. The main one was in January 2009: $35 \mathrm{~cm}$ of new snow in $36 \mathrm{~h}$, with an intensity of $25 \mathrm{~cm} / 24 \mathrm{~h}$, the maximum intensity recorded in the last $20 \mathrm{yr}$ (the previous one was $17 \mathrm{~cm} / 24 \mathrm{~h}$ in 1997). The intensity value is above the 90th percentile of the new snow measured in $24 \mathrm{~h}$ distribution considering only the snowy days. These results agree with the 2008-2009 winter season snow anomaly studies on the southern alpine range (e.g., Valt and Cianfarra, 2009).

\section{Societal impacts of the snowfalls}

The impact scenarios related to the snow emergency are different according to the geographical and anthropic territory features. During the winter 2008-2009 in the mountains, several natural avalanche releases, characterized frequently by large size and heavy destroying power, affected villages and caused interruptions of the main and secondary road systems both down in the valleys and in small villages road access, requiring a long time for the complete and safe snow removal and road re-opening. The avalanches often caused the service breakdowns and damages to the infrastructures in the built-up areas and to the forest heritage. The destructive power of the avalanches was due to their characteristics: the large amount of new snow triggered powder avalanches,

Published by Copernicus Publications on behalf of the European Geosciences Union. 


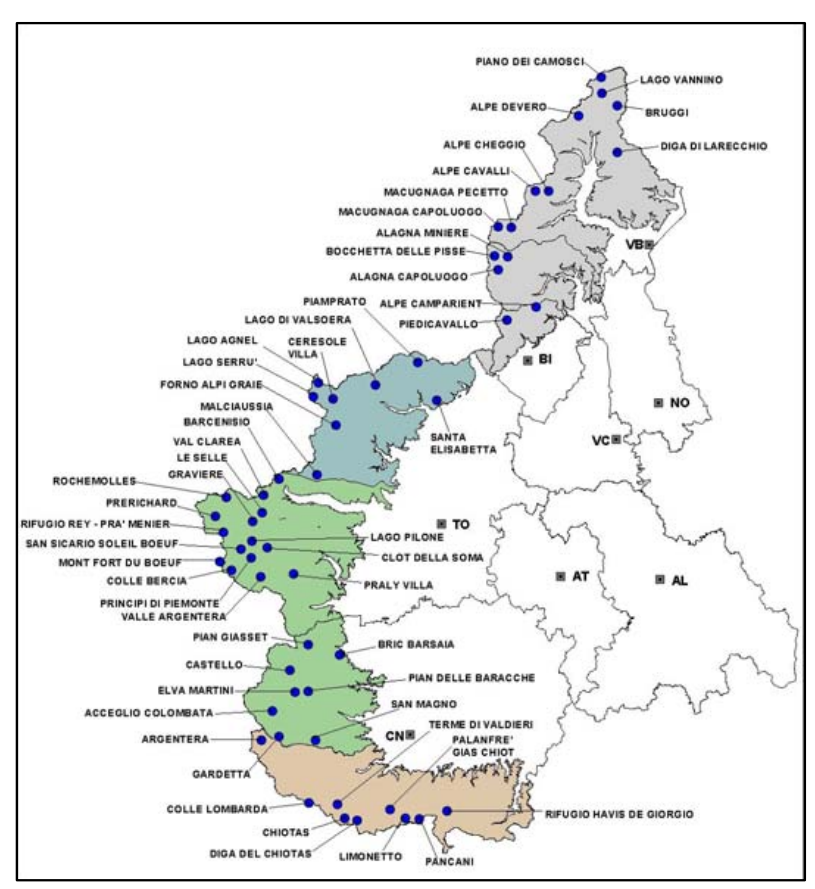

Fig. 1. The snow depth manual stations (blue dots) considered in this study. In colours the Alpine sectors (grey: Northern sector, light blue: North-western sector, green: Western sector, pink: Southwestern sector).

characterized by high speeds (up to $350 \mathrm{~km} \mathrm{~h}^{-1}$ ) and strong pressure over chalets, houses, mountain huts, rural and grazing huts. For example, in the area around Ceresole Reale, a small village at $1570 \mathrm{~m}$ a.s.l. in the upper Orco Valley, in the period between the 15 and the 16 December 2008 many avalanches occurred. Some of them have been classified as extreme avalanches and flowed in areas where no avalanches were reported in the past, over crossing the limits of the official avalanche map. In particular, 4 simultaneous avalanches occurred just above the village and destroyed 6 houses and 12 ha of forest (Maggioni et al., 2009).

Moreover, the hydrogeological risk increased: the rocks and wood transportation by canalized avalanches caused conditions prone to debris flows triggering (Tiranti, 2008) in the late spring and compacted snow accumulations caused the water bags formation inside the snowpack, very dangerous in case of sudden release (Bosco et al., 2007). Strong impacts have been recorded on the mountain wildlife also.

Critical situations due to the snow loading and the snow removal involved all the mountain people directly. Over the plain and the hill country, where the new snow density was generally high, the accumulated snow gave rise to effects related to its load capacity, with the isolation of little residential and rural settlements, several damages on the secondary road system due to the tree and tree branch falls, together with many public services interruptions (electric power and

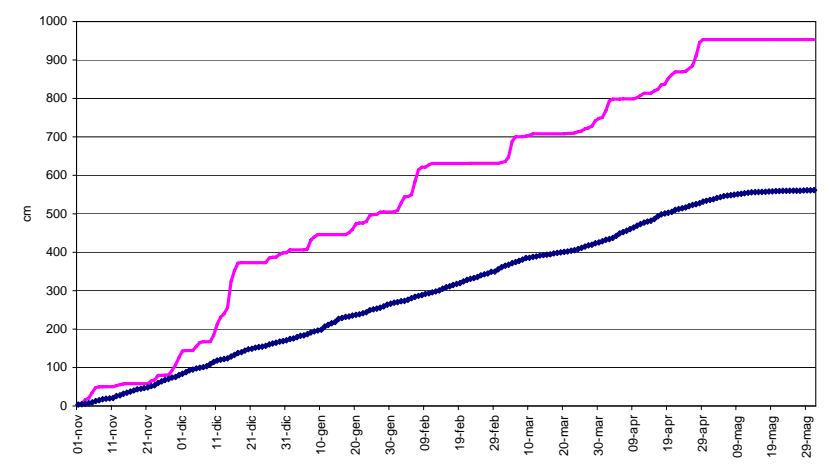

Fig. 2. The daily amount of new accumulated snow measured by mountain weather stations in winter 2008-2009 (pink line) and the 30 yr climatology averaged over the western Alps (blue line).

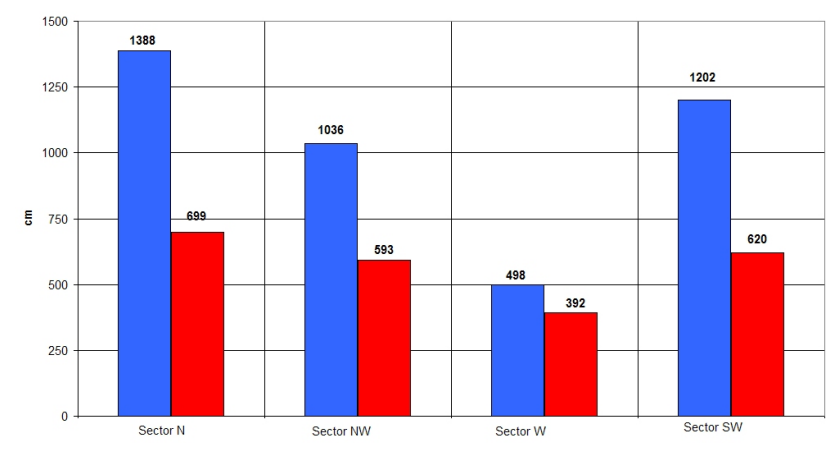

Fig. 3. The total amount of new accumulated snow in the period November 2008-May 2009 (blue) and in the 1996-2009 climatology (red) for four alpine sectors (N, NW, W, SW).

telephone), determining a widespread critical situation. The urban and commuting traffic during the snow emergency enhances the difficulties related to the road management and traffic control over the whole road system in the plains, even with little snow accumulation on the ground. In the towns the snowfalls determined several impacts: the urban traffic slowed up until the complete blockage, the snow accumulated on the sidewalks and parking areas for several days, the sidewalk iced, the snow fell from the roof, tree branches crashed along the roads and temporary infrastructures, involving a large amount of people directly (discomforts, sidewalks snow removal, habit changes, difficulties in getting workplace, school closing...) and asking for unexpected salt supply.

Negative indirect effects also arose from the road frost and intense freezing spells on the plains due to the snow cover persistency. The minimum temperatures were below the 1991-2005 climatology for 41 days in the period January-February 2009 in Torino and for 41 days in Alessandria, where for 5 consecutive days the minima were below the absolute minimum value $\left(-10.6{ }^{\circ} \mathrm{C}\right)$. In the end, several landslides were recorded at low altitudes. In fact, the snow 
Table 1. The heavy snowfall impacts and social relevance.

\begin{tabular}{|c|c|c|}
\hline & Avalanches & Snow amount/loading \\
\hline Direct social impact & $\begin{array}{l}\text { - infrastructure damages } \\
\text { - road and railway system interruptions } \\
\text { - services breakdowns }\end{array}$ & $\begin{array}{l}\text { - villages snowed-up (up to } 10-15 \mathrm{gg} \text { ) } \\
\text { - summer settlement destroyed }\end{array}$ \\
\hline Indirect social impact & $\begin{array}{l}\text { - protection forest destroyed } \\
\text { - limitations in winter tourism } \\
\text { - delay in spring/summer mountain activities }\end{array}$ & $\begin{array}{l}\text { - people involvement in snow removal } \\
\text { - relevant hardships and discomfort }\end{array}$ \\
\hline
\end{tabular}

Table 2. The main criticalities of the 14-22 December 2008 snowfall event.

\begin{tabular}{lr}
\hline Municipalities with avalanche notification & 53 \\
Villages snowed up & 68 \\
Preventive evacuations & 33 \\
Roads and railways interrupted & 243 \\
Municipality affected by power cuts & 173 \\
Number of power users cut off & 97000 \\
Municipality with landslide notification & 95 \\
\hline
\end{tabular}

accumulation over the hill country, besides the snow removal needs and infrastructures damages, caused a rapid soil saturation, which fostered soil slips and debris flows.

The Table 1 summarizes the impacts of the avalanches and the snow loading that affected environment, properties and people for a long time.

To get the real aspects and numbers of the emergency in the mountain area, we report for example the event of 1422 December 2008, when the intensity of the new snow was up to $2 \mathrm{~m}$ in $36-48 \mathrm{~h}$. This determined a snow accumulation on the ground around $2-3 \mathrm{~m}$ at $2000 \mathrm{~m}$ of altitude, almost everywhere, doubling the mean values of the season. The Table 2 reports the main criticalities total numbers during the event and in Fig. 4 the wide territory involved is shown.

The damage costs to the public property caused by the 1422 December 2008 snowfalls have been estimated by the Regione Piemonte to be about 470 millions of euros, giving evidence of the real emergency dimension of the event, never occurred during the last $20 \mathrm{yr}$. A similar amount (541 millions of euros) was evaluated for damages caused by flood event in Piemonte in May 2008.

\section{The technical support to the snow emergency management}

The Regional Agency for Environmental Protection of Regione Piemonte (Arpa Piemonte) is in charge of the operational evaluation of the impacts of extreme events over the region due to natural causes. The Agency, trough the real time monitoring, forecasting, and surveillance of meteorological events and the consequential effects on the territory supports the authorities in the warning issuing (Campus et al., 2007).

During the winter 2008-2009, Arpa Piemonte provided the essential information to open the emergency phase before the risk became high and provided the technical support to the emergency management. The main activities were: the elaboration of up-date target forecasts, the snow and weather real time data delivery, the on-line Agency avalanche information system sharing, the coordination of the avalanche and damage reporting to get a regional updating framework of critical situations, the evaluation of inspection and intervention demands in order to give priorities, the support to the avalanche and snow pack survey and to artificial triggering, the guideline for the local avalanche commissions definition. Moreover the issue of the weather product for the motorways to optimize the closing, cleaning and salting operations and, above all, being at the task force disposal $24 \mathrm{~h}$ a day.

This technical support allowed analysing and highlighting the direct and induced effects of the heavy snowfalls, outlining risk scenarios characterized by different space and time scales. The risk scenarios deployment provided a prompt recommendation list, both for the emergency management and for the natural phenomena evolution surveillance planning to assure the people and property safety. The Table 3 summarizes the different impact time scales for the mountain and plains area, highlighting the long last effects in the mountain and the consequent difficulties in emergency closure decision-making.

The operational implementation of the technical rules for the snow emergency management, tested the first time during the event in a dynamic way, pointed out its drawbacks and potentiality, highlighting the "emergency preparedness" importance at different institutional levels, with the population and stakeholder involvement. Some measures have to be especially underlined: the coordination of the snow monitoring over the territory performed by the local operators and the steps taken locally; the improvement of the tools for the snow pack evaluation to drive the avalanche artificial triggering off, 
Table 3. The different impact time scales for the mountain and plain areas.

\begin{tabular}{|c|c|c|c|}
\hline & Emergency phase & Post emergency phase (spring season) & Post emergency phase (summer season) \\
\hline 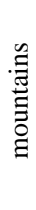 & $\begin{array}{l}\text { avalanches } \\
\text { road/parking/roof snow accumulation } \\
\text { villages cutting off } \\
\text { service breakdowns } \\
\text { infrastructure damages } \\
\text { forest heritage damages }\end{array}$ & $\begin{array}{l}\text { spring avalanches } \\
\text { debris flows } \\
\text { enhancement of floods/discharge } \\
\text { wood silting up } \\
\text { infrastructure damages } \\
\text { forest heritage damages }\end{array}$ & $\begin{array}{l}\text { rural settlement damages } \\
\text { ecological effects (wooded areas, animals, ecosystem services) } \\
\text { delay on spring/summer mountain activities (grazing) } \\
\text { tracks, signs, fences and avalanches barrier damages } \\
\text { infrastructure damages } \\
\text { forest heritage damages }\end{array}$ \\
\hline 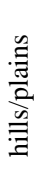 & $\begin{array}{l}\text { road/parking/roof snow accumulation } \\
\text { road icing } \\
\text { service interruptions } \\
\text { frost } \\
\text { air quality worsening }\end{array}$ & enhancement of floods/discharge & \\
\hline
\end{tabular}
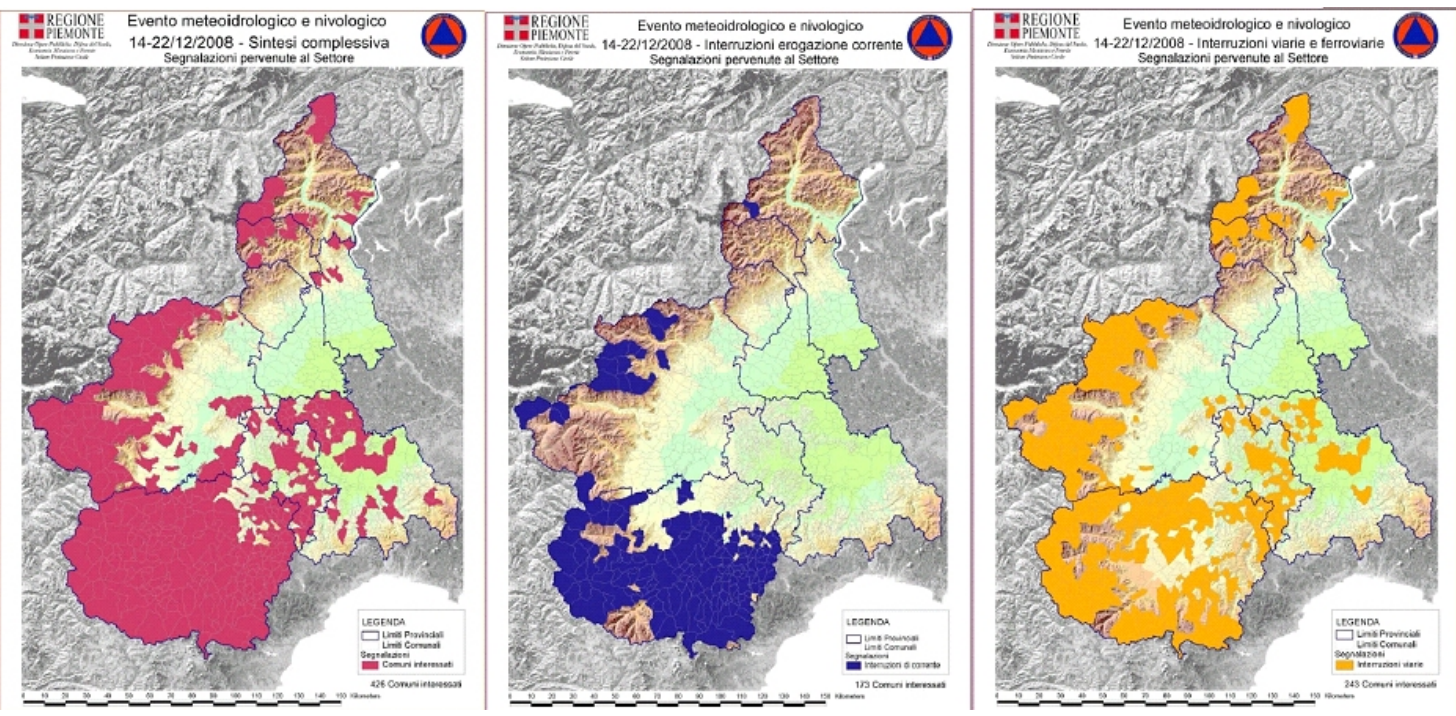

Fig. 4. The territorial distribution of the damages (pink), power services breakdowns (blue) and road interruptions (yellow) caused by the 14-22 December 2008 snowfalls.

in case of snow mass hazard assessment, and their regional coordination. The rapid reporting of avalanches and damages was good, as well as the management of available resources for survey and counteractions. Moreover, because the snow accumulation in the mountain basins represented the biggest water stock of the latest $10 \mathrm{yr}$ (Fig. 5), a tool has been set up to carry on several hydrological simulations forced by different weather scenarios to evaluate the effects on the discharges in case of spring floods, according to a method described by Rabuffetti et al. (2007).

\section{Conclusions and recommendations}

The experience highlights the importance of having defined and shared standards, acknowledged and accepted prevention actions suited to minimize the heavy snowfall effects, with

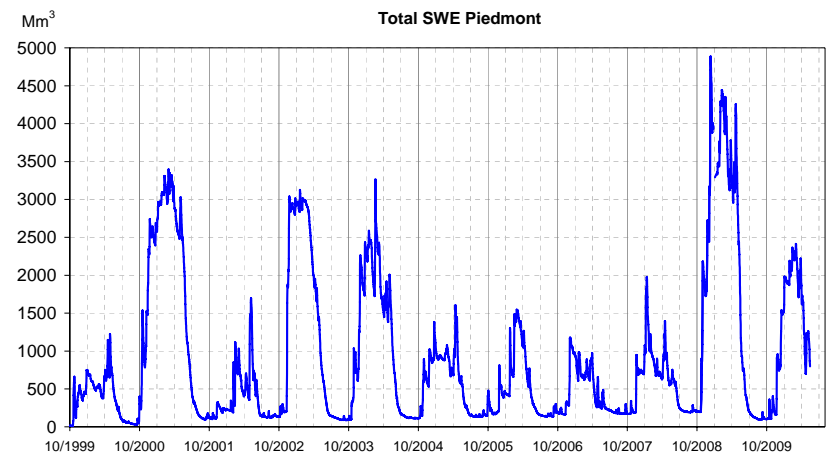

Fig. 5. Snow Water Equivalent (SWE) calculated for the Piemonte Po basin area from October 1999 to February 2010. 
particular attention to the road conditions, to the school system opening/closing and to the preventive information care in order to avoid the missing perception of the risk. Special attention must be paid to the hydrogeological risk condition assessment, forecasting and surveillance. In fact they are enhanced by the winter heavy snowfalls and show their effects during the following season. The improvement in the prediction of the risk evolution scenarios and in the prevention action planning helps the decision making to a considerable degree.

To conclude, a short list of general recommendations for the future cases is presented here:

- setting up of the task force timely (actors/leadership, information flows, responsibility and role assignation, suitable venue guaranteeing data access, elaboration tools, connectivity, comfort, external communication capacity);

- involving of the local actors since the emergency declaration;

- improving of the coordination in the road and motorways closing and opening;

- providing the media, authorities and people with univocal, official and timely information;

- defining of the procedures for artificial avalanche releases, increasing the coordination with the local avalanches committees;

- improving the people preparedness;

- motivating and incentiving volunteers;

- being prepared but with a flexible attitude.

Acknowledgements. The authors would like to thank their colleagues for continuing support and contribution during the snow emergency and for the report preparation.

Edited by: G. Boni

Reviewed by: one anonymous referee

\section{References}

Arpa Piemonte: Rapporto sulle piogge e nevicate intense del 14-17 Dicembre 2008 in Piemonte, http://www.arpa.piemonte.it/index. php? module $=$ ContentExpress $\backslash \&$ func $=$ display $\backslash \&$ ceid $=806$, 2008.

Barbero, S.: Forecasting Natural Phenomena for Emergency Management, Evaluation and prevention of natural risks, Taylor and Francis Group NL/Balkema, 9-14, 2007.

Bosco, F., Gandini, D., Giudici, I., Marco, F., Paro, L., Tararbra, M., and Tiranti, D.: The mass movement of the Rio Frejus (Bardonecchia, NW Italian Alps) on 6 August 2004, Evaluation and prevention of natural risks, Taylor and Francis Group NL/Balkema, 409-447, 2007.

Cordola, M., Turroni, E., Prola, M. C., Bertea A., Zaccagnino, M.,Turco, M., and Martorina, S.: Piogge e nevicate intense del 14-17 Dicembre 2008, Neve e Valanghe, AINEVA ed., 67, 2837, 2009.

Maggioni, M., Caimi, A., Godone, D., Freppaz, M., Bertea, A., Cordola, M. Prola, M.C., Bertoglio, V., and Frigo, B.: The avalanche events of December 2008 in Ceresole Reale, Proceedings of the International Snow Science Workshop, Davos (CH), 2009.

Rabuffetti, D. and Salandin, A.: Analisi delle risorse idriche immagazzinate nel manto nevoso nei bacini alpini, Neve e Valanghe, AINEVA ed., 62, 42-49, 2007.

Rabuffetti, D., Salandin, A., and Cremonini, R.: Hydrological modelling of snow cover in the large upper Po river basin: winter 2004 results and validation with snow cover estimation from satellite, Geo-Environment \& Landscape Evolution II, 293-302, 2006.

Regione Piemonte, Direzione OO.PP., Difesa del Suolo ed Economia Montana a Foreste, Settore Protezione Civile: Evento Meteoidrologico e nivologico del 14-22 Dicembre 2008, 2008.

Tiranti, D.: The sediment gravity flows triggering mechanisms, evolution and sedimentary processes in Western Italian Alps, Ph.D Thesis, Department of Earth Sciences, University of Torino (I) with advising by the Cambridge Quaternary, Department of Geography, University of Cambridge (UK), 100, 2008.

Valt, M. and Cianfarra, P.: Lo straordinario inverno 2008-2009, Neve e Valanghe, AINEVA ed., 67, 4-15, 2009. 